\title{
Corporate Criminal Liability Against Biological Natural Resources and Ecosystems
}

\author{
Jazau Elvi Hasani \\ Airlangga University, Indonesia \\ jazauelvil7@gmail.com
}

\begin{abstract}
Indonesia has various natural resources, including a diversity of natural and biological wealth. Article 33 paragraph (3) of the 1945 Constitution outlines that the state should control natural resources for national prosperity. In the context, biological natural resources can appropriately situate with the conservation effort so that the government plays a vital role in maintaining biological natural resources and their ecosystem. The development of biological natural resources and ecosystems is essentially an integral part of sustainable national development, and efforts to conserve biological natural resources and ecosystems are realized by analyzing and evaluating the existing legislation. This paper aims to discuss the corporate criminal liability in Indonesia in the conservation of biological natural resources and ecosystem. Then, it suggests the possible revisions regarding the biological national resources laws. Revision of the Act on the conservation of biological natural resources has started since 2018 as it is prioritized under the national legislation program. As the revision puts the crucial part of the legal creation, the protection of biological natural resources and ecosystem becomes the government's primary concern because the existing regulation still has no deterrent effect.
\end{abstract}

KEYWORDS: Corporate Criminal Liabilities, Biological Natural Resources and Ecosystems, Crime.

Copyright $\odot 2020$ by Author(s)

This work is licensed under a Creative Commons Attribution-ShareAlike 4.0 International License. All writings published in this journal are personal views of the authors and do not represent the views of this journal and the author's affiliated institutions.

\section{HOW TO CITE:}

Hasani, Jazau Elvi. "Corporate Criminal Liability Against Biological Natural Resources and Ecosystems" (2020) 7:2 Lentera Hukum 189-208.

Submitted: March 1l, 2020 Revised: May 05, 2020 Accepted: July 16, 2020 


\section{INTRODUCTION}

Indonesia has a high level of diversity of natural and biological wealth in one of the mega biodiversity countries. It requires great responsibility to maintain a balance between preserving functions (ecological) and the preservation of biodiversity benefits. ${ }^{1}$ Indonesia's biological natural resources and its ecosystem have an essential position and role in our life. Therefore, it needs to be managed and utilized sustainably, in harmony and balance, for society's welfare. ${ }^{2}$ The development of biological natural resources and their ecosystems is essentially an integral part of sustainable national development as Pancasila's practice. ${ }^{3}$ Sustainable development has three main aims, namely: economic goals (efficiency and growth), ecological goals (conservation of natural resources), and social goals (reducing poverty and equity). ${ }^{4}$ According to the World Commission on Environment and Development (WCED), "The Brundtland Commission," in 1987, sustainable development is a development that balances the fulfillment of human needs with natural environment protection systems. It emphasizes unlimited time that meets the present's needs without compromising future generations' ability to meet their own needs. Consequently, the development will be sustainable and planned to result in environmentally sound, economically viable, and socially acceptable. ${ }^{5}$

The elements of biological natural resources and ecosystems are interdependent and affect each other so that the destruction and extinction of one of the elements will disrupt the ecosystem. ${ }^{6}$ The development must bring the quality of life for all humans, now and the future. The principle of sustainable development is translated into three pillars, where development must prosper economically, socially just, and environmentally sustainable. ${ }^{7}$ To maintain the best use of biological natural resources, efforts are required to conserve the natural resources and ecosystems in specific ways. Those have been determined to be in line with the development.

Biological Natural Resources and Animal natural resources constitute these natural resources, both individually and together, having functions and benefits as an element in forming the environment. ${ }^{8}$ Therefore, efforts are needed to develop biological natural resources in the best way with conservation efforts. So, biological natural resources and ecosystems are always maintained. Conservation of the biological natural resources and its ecosystem aims to ensure the preservation of the biological natural

1 Arif Firmansyah Herliyanto, Sanksi Pidana Terkait Perdagangan Ilegal Satwa Liar yang Dilindungi (2019) 2:3 Jurnal Jurist-Diction, at 844.

Ibid.

3 Law on Conservation of Biological Natural Resources and its Ecosystem No. 5 of 1990, TLN No. 3419.

4 Sali Susiana, Pembangunan Berkelanjutan, Dimensi Sosial, Ekonomi dan Lingkungan (Jakarta: Setjen DPR RI dan Azza Grafika, 2015) at 213.

5 Noor Endah Mochtar et al., Pendidikan Untuk Pembangunan Berkelanjutan (Education Sustainable Development) di INDONESIA: lmplementasi dan Kisah Sukses, (2014) Komisi Nasional lndonesia untuk UNESCO (KNIU) Kementerian Pendidikan dan Kebudayaan at 4.

6 Arif Firmansyah Herliyanto, supra note 1.

7 Darwina Widjajanti, Pengantar Pemahaman Pendidikan konsumsi berkelanjutan (PKB) di Indonesia, (2014) Yayasan Pembangunan Berkelanjutan at 16.

8 Arif Firmansyah Herliyanto, supra note 1 at 2. 
resources and the ecosystem's balance because it is our shared responsibility. Without realizing that the species that have become extinct or endangered have a significant role for an equilibrium ecosystem, the extinction of these species has killed plants and developed an ecosystem and ultimately bring adverse impacts vital for the survival of all creatures in the earth. ${ }^{9}$ The large number of extinctions nowadays is caused by animal poaching and trading, which accelerates the extinction rate of endangered species. High profits obtained may trigger protected animal poaching and trading.

In relation to corporations as the creators of the crime of wildlife, if the corporation commits a crime, then the corporation should be held accountable for the crimes committed either directly shown to the corporation concerned or shown to its management (organs) corporation. Corporations are recognized as criminal law subjects considered to carry out criminal actions that can be held criminally liable. As commonly agreed, at this time, conservation law enforcement has not been able to ensnare corporate actors against wildlife crime, especially those whose concessions are protected wildlife habitats..$^{10}$

Sustainable development in Indonesia refers to Law No. 14 of 1982 on the basic provisions in integrated environmental management. It urges the need to link the implementation of development with environmental management through what is called "Environmentally sound development." In article 4 d, it is stated that one of the goals of environmental management is "the implementation of Environmentally sound development for the benefit of present and future generations. ${ }^{11}$ The crime of protected wildlife still occurs at this time, especially the trade in protected animals. Protected Animals according to Article 4 Paragraph (2) of Government Regulation Number 7 Of 1999 About Preservation of Plants and Animals that protected animals as attached to Government Regulation are orangutan, Javanese tiger, Sumatran tiger, Javanese rhino, turtle, and others. Wildlife poaching and trading are some of the contributors to the decreasing number of Indonesian endemic animals, in addition to changes in land and forest functions.

Indonesia is one of the countries that has the most exceptional natural biodiversity in the world. Indonesia is rich in biodiversity. This richness is limited to the species level - covering wild and domesticated and cultivated, native and introduced species of plants and animals - and to a certain extent, the microbes - and the ecosystem and gene/genome levels. ${ }^{12}$ With the high degree of diversity in all levels, especially the species and ecosystem levels, Indonesia will have better options in

Arif Firmansyah Herliyanto, supra note 1 at 5.

10 Reza Septian, Jalan Panjang Berantas Penyeludupan Satwa Liar Dilindungi, (2019), online: 〈https://www.mongabay.co.id/2019/04/13/jalan-panjang-berantas-penyelundupan-satwa-liardilindungi>.

"l Abdurrahman, Pembangunan Berkelanjutan Dalam Pengelolaan Sumber Daya Alam Indonesia, (2003), Makalah Seminar Pembangunan Hukum Nasional VIII, Badan Pembinaan Hukum Nasional Departemen Kehakiman Dan Hak Asasi Manusia RI at 14.

12 State Ministry of Environment, National Report on the Implementation of the Convention on Biological Diversity, online: https://balaikliringkehati.menlhk.go.id/wp-content/uploads/l-firstnational-report.pdf>. 
utilizing the components in these levels of biodiversity. It has been realized for a long time that biodiversity is a vital asset for development. This asset is ideal for development since it is renewable. The fulfilments of many of the basic human needs are based on the use of biodiversity. ${ }^{13}$ Biodiversity is also vital for the people and the country. It can play multiple roles as sources of income. Communities within and surrounding forests, or other wilderness types, will benefit from their surroundings, containing a high degree of biodiversity. The country also firmly bases its economy on this diversity for generating its national revenue. ${ }^{14}$

Indonesia also is one of the countries that have many practices of crimes against wild animals. Until now, there are still many criminal cases related to poaching and trade in protected wildlife or wildlife, such as the smuggling of yellow-crested cockatoos in Surabaya in 2015, the case of the capture of an elephant ivory carrier in Riau Pekanbaru in January 2015, ${ }^{15}$ and the case of the capture of a tiger skin carrier in the city of Jambi in November 2014.16 The Wildlife Conservation Society, an international NGO that helps the Indonesian police catch traffickers, said that at least 40 percent of illegal wildlife traders in the country used online platforms such as WhatsApp to carry out their transactions since 2011. It also estimated the value of this illicit animal trade at 13 trillion rupiahs ( $\$ 910$ million) a year. ${ }^{17}$ WWFIndonesia's records, since 2012, 36 adult elephants have been found dead in forest areas in the province of Nanggroe Aceh Darussalam. The majority of elephant deaths are caused by poisoning, while some cases are caused by stun or snares in oil palm plantations. The number of elephant deaths due to poaching was 208 individuals in the period 1999-2015. ${ }^{18}$

In practice, this current legislation is ineffective in protecting animals' habitats against humans. National legal instruments that protect wild animals and plants do not yet have full provisions that refer to CITES, and the threat of existing sanctions also does not cause a deterrent effect of perpetrators of crime. Legislative revisions in conservation, animal protection, or wildlife are needed to develop international legal instruments. ${ }^{19}$ The modus operandi of illegal wildlife traffickers is through conventional buying and selling, often carried out directly in traditional markets or social media. ${ }^{20}$ Protected animal trafficking is made not only by individuals but also by corporations, which defines as part of systematic crime networks-data compiled by WWF

13 Ibid.

14 Ibid.

15 Fathi Hanif, Upaya Perlindungan Satwa Liar Indonesia Melalui Instrumen Hukum dan Perundangundangan, (2015) 2:2 Jurnal Hukum Lingkungan at 1.

16 Radesman Saragih, Oknum Perbakin Jambi Tertangkap Jual Kulit Harimau, (2015), online: 〈https:/www.beritasatu.com/kesra/287990/oknum-perbakin-jambi-tertangkap-jual-kulit-harimau〉.

17 Basten Gokkon, Indonesia Conservation Bill is Weak on Wildlife Crime Critics Say, (2018), online: 〈https://news.mongabay.com/2018/04/indonesian-conservation-bill-is-weak-on-wildlife-crimecritics-say/>.

18 Fathi Hanif, supra note 15.

19 Ibid.

20 Arif Firmansyah Herliyanto, supra note 1 at 1. 
Indonesia about animal crime in Indonesia. Perpetrators of smuggling turtles in Papua, arrested by the police. On the other hand, officers had found 5050 turtles as evidence. ${ }^{21}$ The Semarang Quarantine Center had found 296 birds of various species from raids smuggling activity. ${ }^{22}$ The Ministry of Environment and Forestry (KLHK) has handled 187 cases of wildlife trade during the last three years. The total confiscation reached 10 thousand items, including 117 wild animals, 213 sacks of turtle shells, 248 kilograms of pangolin scales, and 6,168 reptile skin pieces. ${ }^{23}$ In 2015, the Surabaya Regional Police found 5 tons of pangolin meat in the raid of protected wildlife illegal trade. ${ }^{24}$ The trend of illegal wildlife trade online is widespread. According to International Animal Rescue (IAR) Indonesia, more than 80 percent of the animals' online social media market had caught sourced from nature. IAR data had shown that during 2012-2018 there were 64 people netted operations. A total of 2,957 slow loris trade ads were monitored on social media. $^{25}$

Indonesia was publishing the regulation on the convention on international trade of endangered wild species of fauna and flora (CITES) through the presidential decree (Kepres) No.43 of 1978 concerning ratification of the convention on international trade of endangered wild species fauna and flora (CITES) to protect various types of animals and plants. The Government of Indonesia has ratified the Convention on Biological Diversity through an act (Act No. 5, 1990, concerning the conservation of Living Resources and Their Ecosystems). The Indonesian government realized the regulation and protection by establishing Law No. 5 of 1990 concerning Conservation of Biological Natural Resources and Ecosystems. The Law on Conservation of biological natural Resources and Ecosystems still has weaknesses. There is no regulation regarding crime carried out by corporate perpetrators.

Corporations as subjects of criminal law have brought about fundamental changes in criminal law, initially, criminal law only recognizes humans as legal subjects. According to Rudi Prasetyo, the word corporation is a term commonly used among criminal law experts to refer to what is commonly referred to as a legal entity in Dutch and legal entities or corporations in English in the field of civil law. ${ }^{26}$ The principle of "no criminal also influences the basic theory of accountability in criminal law without error." Therefore, the basic theory of responsibility in criminal law is also adopted

21 Reza Septian, supra note 10.

22 Akhmad Safuan, Penyeludupan Ratusan Burung Langka Digagalkan, (2019), online: 〈https://mediaindonesia.com/read/detail/225754-penyelundupan-ratusan-burung-langka-digagalkan〉.

23 Keisyah Aprilia, UU Konservasi Lemah Hadapi Perdagangan Satwa Liar, (2018), online: 〈https://www.benarnews.org/indonesian/berita/uu-lemah-hadapi-perdagangan-satwa-liar05022018122431.html>.

24 Muhammad Yazid, Akan Ada Hukuman Minimal Bagi Pemburu Satwa Langka, (2015), online: https://nasional.kontan.co.id/news/akan-ada-hukuman-minimal-bagi-pemburu-satwa-langka>.

25 Baehaqi Almutoif, Hukuman Pelaku Perdagangan Kukang Masih Rendah, (2019), online: 〈https://jatimnet.com/hukuman-pelaku-perdagangan-kukang-masih-rendah〉.

26 Muladi Dwidja Priyatno, Pertanggungjawaban Pidana Korporasi, (Jakarta: Kencana Prenada Media Group, 2011), at 27 mengutip dari Rudi Prasetyo, Perkembangan Korporasi dalam Proses Modernisasi dan Penyimpangan-Penyimpangannya, (1989) Makalah disampaikan pada Seminar Nasional Kejahatan Korporasi di FH UNDIP at 2. 
according to the principle of "no criminal without error" that incorporates criminal responsibility.

Corporations are considered to be able to have errors, and this is sourced from the attributions of deeds to the management or directors of the corporation in carrying out its functionary duties. Besides, several theories of criminal liability have also emerged that override the element of error. So in this theory, the principle of "no criminal without error" does not apply. Therefore, these theories see criminal liability by linking it to the maxim "actus non facit reum nisi mens sit rea." theories created to accommodate the possibility of imposing criminal liability and criminal liability on corporations, namely identification theory, strict liability, vicarious liability, and functional dadchap. functioneel daderschap theory sees criminal liability by linking it to the elements of actus reus and mens rea.

Legal rules govern the protection of protected wildlife and even given criminal threats, violations still occur. Massive exploitation in the natural resource sector, especially the diversity of wildlife, has led to violations of the law committed by those who exploit nature, the majority of which are companies with powerful capital. The possible chance for corporations to commit wildlife crimes is vast. Some of the cases that were found as corporate crimes against protected wildlife are the extinction of primates in Kalimantan because they are considered pests in the area of oil palm plantations so that companies ultimately kill ${ }^{27}$ The Conservation Policy Working Group (Conservation Working Group) explains that law enforcement on conservation has not yet ensnared many wildlife crime perpetrators as organized crime. It has not yet managed to ensnare corporations, especially those whose concessions are protected wildlife habitats. ${ }^{28}$ Another weakness is that this regulation only regulates people as subjects of wildlife crime laws. The formulation of corporate crime against wildlife is still not regulated. ${ }^{29}$

The initial development of corporate conviction that corporations can be held accountable because corporations are "real entities." Corporate actions can be separated from natural human actions in the corporation (corporate policy). Criminal liability for a corporation that commits a crime against protected wildlife is a crime committed by a corporate legal subject. The corporate punishment approach refers to the general definition of corporations in the legislation, namely "a collection of people and/or capital, both legal and non-legal entities." However, the current legislation has limited the corporation's legal subjects to only those with legal status.

In criminal acts, there are two legal subjects, namely natural persons and corporate actors. At present, the corporation appears as an artificial legal entity (legal

27 Kustin Ayuwuragil, RKUHP Disebut Tak Bisa Bikin Jera Kejahatan terhadap Satwa, (2018), online: 〈https://www.cnnindonesia.com/nasional/20180530163318-12-302304/rkuhp-disebut-tak-bisa-bikinjera-kejahatan-terhadap-satwa>.

28 Reza Septian, supra note 10.

29 Della Syahni, Soal Kejahatan Satwa Liar Masuk Revisi KUHP Begini Pandangan Mereka, (2018), online: 〈https://www.mongabay.co.id/2018/06/04/soal-kejahatan-satwa-liar-masuk-revisi-rkuhpbegini-pandangan-mereka/>. 
fiction) whose existence can be felt by the public-facing the fact that corporations in their activities have harmed society in protected wildlife crime. Thus, it takes a set of rules in the criminal law regime that functions as a moral condemnation of corporate actions in protected wildlife.

Two draft regulations governing wildlife protection are still at the DPR draft stage, namely Revision of Law Number 5 of 1990 concerning Conservation of Living Natural Resources and Ecosystems and the RKUHP, regulating wildlife protection. The purpose of the draft and revision is the existence of criminal reinforcement for violations of laws related to wildlife protection. Corporate criminal liability for wildlife is still in the process of discussing the RKUHP. It is motivated by crime on wildlife more or less committed by corporations who want to profit from Indonesia's natural resources substantially. So that the Criminal Code will regulate legal subjects who commit environmental destruction and crime to wildlife, both individual and corporate legal subjects. ${ }^{30}$

\section{ANALYSING LAW NUMBER 5 OF 1990 ON THE CONSERVATION OF BIOLOGICAL NATURAL RESOURCES AND ECOSYSTEMS}

The terminology of criminal act (strafbaarfeit) is a basic definition in criminal law. According to Simon's opinion, an action can be classify as criminal act if it fulfills various elements as follows: ${ }^{31}$

a. Human action (legal subject), both active and passive acts;

b. Formulated and threatened with a crime in a statutory regulation;

c. Unlawful;

d. Made with mistakes

e. By people who can take responsibility

Criminal liability is a form of the offender's ability to account for a criminal offense that violates the law. Criminal regulations only refer to prohibited and threatened acts with a crime. The criminal law that develops in Indonesia, there is the principle of accountability, that is "not convicted if there are no mistakes" (Geen straf zonder schuld; Actus non facit reum nisi mens rist rea). The elements of fault relating to criminal responsibility are ${ }^{32}$

a. Committing a crime;

b. Above a certain age and able to takes responsibility;

c. With deliberately or negligently;

d. There is no excuse for forgiveness.

30 Dewi Purningsih, Kejahatan Satwa Liar dan Tanggungjawab Korporasi dalam RKUHP, (2018), online: 〈https://www.greeners.co/berita/kejahatan-satwa-liar-dan-tanggungjawab-korporasi-dalam-rkuhp/.

31 Rasamala Aritonang, Tata Cara Penanganan Perkara Pidana Korporasi, (2017) Tim Pokja Penyusunan Pedoman Pertanggungjawaban Korporasi, Mahkamah Agung RI dan Komisi Pemberantasan Korupsi at 38 .

32 Didik Endro Purwoleksono, Hukum Pidana (Surabaya: Airlangga University Press, 2013) at 63. 
Policy System for Protecting Animal Crimes Protected in Positive Criminal Law discusses the position and regulation of protected wildlife acts described under the three main problems of the criminal law: acts (criminal acts), people (fault or criminal liability ) crimes. The provisions regarding the Criminal Acts against protected Animals are only regulated in Law No.5 of 1990. Law Number 5 of 1990 concerning Conservation of Biological Natural Resources and Ecosystems (Article 21). According to Article 21 Paragraph (2), Everyone is prohibited from:

a. capture, injure, kill, save, own, maintain, transport, and trade animals protected while alive;

b. storing, possessing, maintaining, transporting and trading protected animals in a state of death;

c. eject protected animals from one place in Indonesia to another place inside or outside Indonesia;

d. trade, save or have skin, body, or other parts of animals protected or items made from such parts or remove them from a place in Indonesia to other places inside or outside Indonesia;

e. take, destroy, destroy, trade, store or own eggs, or protected animal nests..

As stated in Article 21(2) of Law No. 5 of 1990, the killing of protected animals is expressly a criminal offense. This legislation outlines the element of fault that covers criminal offense. In Article 40, criminal provisions covering every criminal act against are based on an Article in this legislation. The provisions that cover criminal acts are outlined in Article 40 paragraph 2 concerning criminal intention and paragraph 4 regarding criminal negligence. Therefore, there must be two types of wrongdoing (mens rea) of a corporation that results in an actor having to account for his actions, namely intentional or negligence. This principle applied to prove the criminal liability of the actor's mens rea. First, criminal liability in this law is contained in Article 40 regarding criminal acts against animals; criminal liability is imposed on people. This can be proven from the element of whosoever referred to Article 40 paragraph (2) which can be criminally accountable a person. Second, Law Number 5 of 1990 adheres to a particular maximum criminal system, and its type consists of imprisonment and fines (adhering to the cumulative criminal threat formulation system using the word "and," where the judge in imposing his decision must impose a sentence The second criminal sanction is regulated in the formulation of the article, namely imprisonment and fines.

The Law Number 5 of 1990 concerning the conservation of biological natural resources and ecosystem, the article containing few reasons for criminal based on the theory of punishment as a justification in Article 22, whose articles are as follows:

(1) Exemptions from prohibitions, as referred to in Article 21, can only be conducted for research, science, and/or purposes rescue of the relevant plant and animal species.

(2) Included in the rescue, as referred to in paragraph (1), are giving or exchanging plant and animal species to other parties outside the country with Government permission. 
(3) Exemptions from prohibitions on catching, injuring, and killing protected animals can also be done in terms of due to some reason that animal protected endangering human life.

(4) Further provisions as referred to in paragraph (1), paragraph (2), and paragraph (3) regulated by Government Regulation.

There are three subjective elements of criminal conditions. The element of deliberate and negligence (culpa) and can be accounted for three scopes of fault in the broadest sense. Besides, no reason, excusatory, is also part of a mistake. ${ }^{33}$

\section{LEGISLATING CORPORATE CRIME LIABILITY IN THE PROTECTED ANIMALS CRIME}

Law No. 5 of 1990 does not have any corporation liability regulation for the crime of protected animals. As a result, law enforcement is poor due to criminal threats in Law No. 5/1990 on the Protection of Biological Natural Resources and Ecosystems. ${ }^{34}$ Corporation is a term used by criminal law experts to refer to what is called a legal entity in the field of civil law (rechtsperson). The legal system in Indonesia, known as legal subjects, is divided into two forms: first, human (person), and legal entity. ${ }^{35}$ The corporation is commonly used by criminal law experts to refer to what is commonly used in the civil law field, as a legal entity, or as a right person in the Dutch language. ${ }^{36}$ In its development, however the corporations are viewed not only as legal entities or legal entities, ${ }^{37}$ but more generally, as a structured collection of individuals or property, whether legal entities or not. ${ }^{38}$

Legal entities are legal subjects who have their rights and obligations even if they are not human (person), in this case, in the form of an entity or association consisting of a group of people who enter for a particular purpose and have some property. ${ }^{39}$ In order to hold corporate criminal liability as the subject of a criminal offense, the procedures and procedures for corporate inspection are regulated in the Republic of Indonesia Supreme Court Regulation No. 13 of 2016 concerning Procedures for Handling Criminal Cases by Corporations. This Supreme Court Regulation is useful for Law Enforcement officials in handling criminal cases conducted by corporations. According to Article 1 of the general provisions governed by the corporate definition that Corporations are organized groups of people and/or assets, both legal entities and non-legal entities. It

Andi Hamzah, Hukum Pidana Indonesia (Jakarta: Sinar Grafika, 2017) at 105.

Keisyah Aprilia, supra note 23.

35 Wahyu Beny Mukti Setiyawan, Pertanggungjawaban Korporasi dalam Tindak Pidana Korupsi, Fakultas Hukum Universitas Surakarta at 3.

36 Agus Budianto, Delik Suap Korporasi di Indonesia (Bandung: CV. Karya Putra Darwati, 2012) at 56.

37 Rochmat Soemitro, Hukum Perseroan Terbatas Yayasan dan Wakaf (Bandung: PT Eresco, 1993) at 10.

38 Muladi, Pertanggungjawaban Pidana Korporasi, (2013) Harian Kompas, at 6.

39 Wahyu Beny Mukti Setiyawan, supra note 35. 
also regulates explicitly other types of corporations, namely the parent corporation and subsidiary companies. ${ }^{40}$

Corporate criminal liability has been expressly regulated in Article 3 that "Criminal acts by Corporations are crimes committed by people based on work relationships, or based on other relationships, both individually and jointly acting for and on behalf of the corporation in or outside the Corporate Environment." Consequently, the procedural law regarding handling corporate criminal acts has provided comprehensive arrangements for corporations' prosecution. ${ }^{41}$ The elements of corporate criminal liability consist of the theory of corporate criminal liability, criminal system, mens rea, deliberate, and negligence, and actus reus.

Corporations, as subjects of criminal law, have brought about fundamental changes in criminal law. Initially, criminal law only recognizes humans as legal subjects. the principle of "no criminal also influences the basis of accountability in criminal law without error." Therefore, the basic theory of responsibility in criminal law is also adopted under the principle of "no criminal without error," incorporates criminal responsibility. However, in its development, several criminal liability theories put aside the element of error. So in this theory, the principle of "no criminal without error" does not absolutely apply. These theories see criminal liability by linking it to maxim "actus non facit reum nisi mens sit rea". theories created to accommodate the possibility of imposing criminal liability and criminal liability on corporations, namely identification theory, strict liability, vicarious liability, and functioneel dadchap. functioneel daderschap theory sees criminal liability by linking it to the elements of actus reus and mens rea.

Corporations are considered to be able to have errors originating from attributions of deeds to the management or directors of these corporations in carrying out their functionary duties. Thus, the corporation can still have mistakes that originate from the element of error (intentional or negligence) can be held by the organs of the corporation or other workers who set organizational policies. ${ }^{42}$ Van Bemmelen, given the corporation's intentions, argues that the shared knowledge of most members of the board of directors can be regarded as intentional of the corporation, if possible, as a conditional intentional. ${ }^{43}$ According to Jan Remmelink, concerning corporations, the element of intent can be carried out with the fulfillment of several different people's

40 Peraturan Mahkamah Agung Republik Indonesia Nomor 13 Tahun 2016 Tentang Tata Cara Penanganan Perkara Tindak Pidana Oleh Korporasi, Berita Negara Republik Indonesia Tahun 2016 Nomor 2058.

41 Ibid.

42 Terhadap pandangannya tersebut, muncul kritik dari legislatif yang menganggap rumusan tersebut terlalu sempit dalam hal mengadakan unsur kesalahan pada korporasi. Mereka berpendapat, bahwa untuk tindakan tertentu, patut diterima dan dipertahan kan pandangan bahwa selain melalui tindakan fungsionaris pengurus, melainkan juga melalui tindakan pegawai rendahan kesalahan korporasi dapat diadakan. Jan Remmelink, Hukum Pidana (Komentar atas Pasal-Pasal Terpenting dari Kitab Undang-Undang Hukum Pidana Belanda dan Padanannya dalam Kitab Undang-Undang Hukum Pidana Indonesia) (Jakarta: PT Gramedia Pustaka Utama, 2003) at 108.

43 J.M. Van Bemmelen, Hukum Pidana I: Hukum Pidana Material Bagian Umum (Bandung: Binacipta, 1986) at 237 
offense elements. ${ }^{44}$ Suprapto, in response to these opinions, agreed that corporate mistakes could be made based on intentional or negligence found in the people who become the instrument. ${ }^{45}$ The error is not individual because it is associated with a collective body. ${ }^{46}$ Thus, the corporation can still have errors taken from the management or directors in carrying out their functionaries. It is because of the corporation in doing or not doing, through or represented by individuals. Thus, the principle of "no criminal without error" can still be applied to the corporation.

According to Reksodiputro's opinion, Indonesia in its arrangement regarding corporations as subjects of criminal law, has three models of corporate criminal responsibility: ${ }^{47}$

1) Corporate management as the maker and responsible corporate management

2) Corporations as responsible makers and administrators

3) The corporation as a maker and also a responsible corporation.

According to Sutan Remy S. and Mardjono Reksodiputro's opinion on the corporate criminal liability model, a criminal liability model can be adopted for the corporation, namely the corporation, as a criminal offense, and the corporation itself must bear criminal liability. Perpetrators of wildlife crime to be included as corporations can regulate the subject of the law "everyone" as formulated in the Law on the conservation of biological natural resources and their ecosystems. With the adoption of corporate understanding as to the subject of criminal acts, corporations as both legal entities and non-legal entities, are considered capable of carrying out criminal acts and can be accounted for in criminal law (corporate criminal responsibility).

Regarding corporate criminal liability, Hulsman stating that the element of fault (intentional or negligence) can be carried out by the organs of the corporation or other workers who set organizational policies. ${ }^{48}$ Therefore, about such incidents, there must be a particular connection between the actions of these people. ${ }^{49}$ Corporate crime is an organizational crime. ${ }^{50}$ corporations can be held accountable for what their employees have done, known as "actus reus," which means that the actions taken should fall within their jurisdiction scope. In other words, it is still within the scope of corporate duties in carrying out that mission. Without a purpose and achievement of the corporation's goals, a corporation will not be established. Therefore, persons' obligation to be accountable for the corporation has shifted to accountability regarding the

44 Ibid at 109

45 Muladi, Dwidja Priyatno, supra note 26 at 105.

46 Ibid.

47 Mardjono Reksodiputro, Pertangungjawaban Pidana Korporasi dalam Tindak Pidana Korporasi (Semarang: FH-UNDIP, 1989) at 9.

48 Jan Remmelink, supra note 42.

49 Ibid.

50 Reda Manthovani, Penuntutan Korporasi Sebagai Pelaku Tindak Pidana Dalam Kejahatan di Sektor Kehutanan: Optimalisasi Penggunaan Undang-Undang Pencucian Uang Dalam Pembuktian Tindak Pidana di Sektor Kehutanan di Indonesia yang Dilakukan Oleh Korporasi, (2010) Jurnal Indonesian Corruption Watch at 4. 
criminal offense. ${ }^{51}$ According to Van Bemmelen's Opinion, the corporation can still have fault taken from the management or directors in carrying out their functionaries. It is because of the corporation in doing or not doing, through or represented by individuals. In its development came the doctrines that set aside the principle of "no criminal without fault ${ }^{52}$

In Indonesia, the regulation of corporations as legal subjects has begun in some legislation, in Article 49 of Law No. 9 of 1976 concerning Narcotics Crimes, Article 1 point 20 of Law Number 35 of 2009 concerning Narcotics, Article 1 point 13 and Article 59 of Law Number 5 of 1997 concerning Psychotropics, Article 1 point 19 of Law Number 22 of 1997 concerning Narcotics, Article 1 numbers 10 and 14 and Article 6 of Law Number 8 of 2010 concerning Prevention and Eradication of Money Laundering Crimes. Thus, Indonesia has recognized corporate criminal liability since $1951 .{ }^{53}$ According to Law Number 32 of 2009 concerning Environmental Protection and Management. Provisions regarding the recognition of corporations as subject to criminal law can already be paid attention to in the General Provisions section of Article 1 Number 32, stating: "Every person is an individual or business entity, both legal and non-legal." So, this paper argues the following matters:

\section{A. The Model of Corporate Criminal Liability}

The Corporate Criminal Liability Model in Indonesia itself, in its arrangement regarding corporations as subject to criminal law, has three models of corporate criminal liability. As Mardjono Reksodiputro in his paper, the corporation criminal liability model is as follows: 1) The corporate management as the maker and responsible management of the corporation 2) The corporation as the maker and responsible management 3) The corporation as the maker and also the responsible corporation.

Based on the corporate criminal liability model for protected wildlife crime, a second model can be charged, namely the corporation as the maker and responsible administrator. In the corporate criminal liability model, the corporation is the maker and responsible administrator. Then the corporation as a legal subject is recognized as being able to commit criminal acts, but the management still bears the responsibility. ${ }^{54}$ Muladi and Dwidja think that the criminal liability model is that the management is designated as responsible for what is seen as done by the corporation: what is carried out by corporate equipment according to authority based on its articles of association. ${ }^{55}$ More clearly, the corporation's management or leader is responsible for the actions carried out by someone or several people, which are considered the corporation's actions. It is due to the inherent obligation of the management or leader. According to Mardjono Reksodiputro, the Criminal Code has adopted a criminal liability model. The provisions in the Criminal Code that govern corporate management's criminal liability,

51 Wahyu Beny Mukti Setiyawan, supra note 35 at 7.

52 Ibid.

53 Reda Manthovani, supra note 50.

54 Muladi, Dwidja Priyatno, supra note 26 at 87.

55 Ibid at 89. 
namely Article 59, through a different interpretation. ${ }^{56}$ According to him, this provision stipulates that corporations can commit criminal acts, only that the management bears the responsibility unless the management can prove that he is not involved. ${ }^{57}$

This second corporate criminal responsibility model can be applied to protected animal crime. According to the second model, the corporation as the maker and manager is responsible. Corporate crime against wildlife protected in criminal liability, the corporation commits criminal acts against wildlife whose responsibility is borne by Ithe corporation's management. More clearly, the corporation's management or leader is responsible for animal crimes committed by a person or several people, which are considered acts of the corporation. It is due to the inherent obligation of the management or leader to control the company. This provision stipulates that corporations can commit crimes against protected wildlife, then the responsibility is borne by the management of the company because the management is proven to be involved in criminal acts.

\section{B. Determination of the Corporate Criminal Liability Doctrine}

The imposition of criminal liability for wildlife trafficking protected by corporations can be explained according to the theory of Corporate Criminal Responsibility Doctrine Vicarious Liability. ${ }^{58}$ The doctrine of vicarious liability is a form of corporate criminal responsibility. Criminal liability is then imposed on someone for another person (the legal responsibility of one person for the wrongful acts of another). ${ }^{59}$ Liability refers to criminal liability in acts committed by others within the scope of work or position. ${ }^{60}$ The existence of a subordinate relationship between employers and workers or principles with the agent is the main requirement in the vicarious liability. ${ }^{61}$ The relationship then becomes the basis for the imposition of criminal liability to someone for the actions of others. ${ }^{62}$

The vicarious liability doctrine is a corporate criminal liability doctrine adopted from civil law. ${ }^{63}$ The criminal responsibility theory is to link the elements of the actus reus and mens rea, which means someone who acts through another person thought he had committed actions. ${ }^{64}$ This doctrine is applied to the law of tort. ${ }^{65}$ There is a relationship between superiors and subordinates (workers and employers), where the

\footnotetext{
Ibid at 186.

Mardjono Reksodiputro, supra note 47.

Barda Nawawi Arief, Kapita Selekta Hukum Pidana (Bandung: Citra Aditya Bakti, 2003) at 233-238.

59 Romli Atmasasmita, Asas-Asas Perbandingan Hukum Pidana (Jakarta: Yayasan Lembaga Bantuan Hukum Indonesia, 1989) at 93.

60 Muladi, Dwidja Priyatno, supra note 26 at 113.

61 Sutan Remy S., Pertanggungjawaban Pidana Korporasi (Jakarta: Grafiti Pers, 2006) at 87.

62 Aulia Ali Reza, Pertanggungjawaban Korporasi dalam Rancangan Kitab Undang-undang Hukum Pidana, (Jakarta: Institute for Criminal Justice Reform, 2015) Aliansi Nasional Reformasi KUHP Jurnal Institute for Criminal Justice Reform (ICJR) at 20.

63 Loebby Luqman, Kapita Selekta Tindak Pidana di Bidang Perekonomian, (Jakarta: Datacom, 2002) at 84.

64 Black's Law Dictionary, Eighth Edition (United States of America: West, 2004).

65 Sutan Remy Sjahdeini, supra note 61 at 179.
} 
employer is responsible for workers' mistakes. ${ }^{66}$ However, accountability is limited as long as the worker's actions are carried out. A subordinate is still within the work scope, and the responsibility is proven. ${ }^{67}$

This doctrine teaches about a criminal liability that is imposed on someone for the person's action. ${ }^{68}$ Liability, referred to as criminal liability, occurs in the case of acts committed by another person within the scope of work or position. ${ }^{69}$ A subordinate relationship between the employer and the worker or principle with the agent is the main requirement. ${ }^{70}$ The relationship then becomes the basis for the imposition of criminal liability to someone for others' actions. There is a condition of the relationship between the employer and the laborer. It is portrayed as the relationship between the principal (agent) with the agent (agent), or between employer and employee. ${ }^{71}$ Lord Russell LJ believes that an employer can only be liable for criminal liability if his employees' actions are carried out within the framework of his work scope. ${ }^{72}$ Boisvert said that this doctrine deviated from the mens rea doctrine. ${ }^{73}$ This deterrence is made due to the employer's responsibility for workers in carrying out works. ${ }^{74}$

Through the vicarious liability doctrine, the corporation can be held responsible for acts committed by the parties that have been given attribution of duties by the corporation based on a working relationship. It is not closely linked to workers who join the company's organs, but also to agents or representatives who are outside the company's organs, with limits as long as the actions carried out by the workers, agents, or representatives are limited to the scope of work or the attribution given to the worker or agent. Wildlife crime committed by the parties to be given the corporate attribution task is based on employment inside and outside the corporate organ to perform acts included in Article 21, paragraph 2, that each person is forbidden to:

a. capture, injure, kill, store, possess, care for, transport and trade protected animals in a state of life;

b. storing, possessing, maintaining, transporting and maintaining protected animals that are dead;

c. eject protected animals from one place in Indonesia to other places inside or outside Indonesia;

d. trade, store or possess skin, body, or other parts of protected animals or items made from animal parts or remove them from a place in Indonesia to other places inside or outside Indonesia;

e. take, destroy, destroy, trade, store, or own eggs and/or nests of protected animals.

66 Ibid.

67 Ibid.

68 Romli Atmasasmita, supra note 59.

69 Muladi, Dwidja Priyatno, supra note 60.

70 Sutan Remy S., supra note 61.

71 Sutan Remy S., Ibid at 91.

72 Gary Scanlan, Christopher Ray, An Introduction to Criminal Law (London: Blackstone Press Limited, 1985) at 121, cited by Sutan Remy S., supra note 61 at 89.

73 Anne-Marie Boisvert, Corporate Criminal Liability, as cited by Sutan Remy S., supra note 61 at 91.

74 Sutan Remy S., supra note 61 at 92. 
The actions of workers who commit crimes of protected wildlife will be attributed to company actions. According to the vicarious liability doctrine, workers' actions can be qualified as a criminal liability by the company. Corporate criminal liability in wildlife crime protected according to the vicarious liability doctrine, is a criminal liability that occurs in criminal acts against protected wildlife and committed by people within the scope of work or position. Due to the subordination relationship between the employer and the worker or principle with the agent. The relationship between the worker and the employer is the basis for the company's imposition of criminal liability for the crime of animals committed by its workers. Besides, there is a distribution of actions from the employer to the worker. The company can be liable for criminal liability if its employees' actions in the context of fulfilling duties within the scope of work result in the reduction of wild animals in their natural habitat. Wrongdoings by criminal offenders can be categorized as intentional to commit wildlife crimes or negligence by employers because they do not supervise their workers carrying out their duties or within their work scope.

The Law relating to the crime of protected animals should include matters that have not yet been regulated. There are criminal guidelines for corporations for the crime of protected wildlife including the corporation as a subject of crime, the determination of criminal sanctions for the corporation, and the determination of condition the corporation can be accounted for criminal liability. ${ }^{75}$ In connection with the form of liability of a legal entity (corporation), namely the punishment imposed on a legal entity (the corporation itself) then concludes the provisions regarding the conviction of a legal entity or association, including that in principle, punishment is not directed to legal entities or associations but to a group of people who work together for something or purpose who have joint wealth for a purpose incorporated in the body. ${ }^{76}$ Also, there are some provisions which must deviate from the application of criminal law (general) to these bodies in the case of bodies that can be convicted, as such it is possible to impose the crime of deprivation of liberty (imprisonment, closure, confinement) on him and not criminal penalties may be replaced with imprisonment. ${ }^{77}$

Legal entities are legal subjects who have their rights and obligations even though they are not human (person). If a corporation is involved in a criminal act, such a view implies that the corporation cannot be held responsible for an act, but rather the management that carries out the act. ${ }^{78}$ Thus, only the management can be threatened with criminal and convicted because who is domiciled as a legal subject, the management still carries out the corporation carrying out its actions. ${ }^{79}$

Considering the determination and application of criminal sanctions against the corporation, the provisions regarding corporate criminal liability in outlined in Article

75 Ibid at 11.

76 Wahyu Beny Mukti Setiyawan, supra note 35 at 6.

77 Ibid.

78 Roeslan Saleh, Tentang Tindak-Tindak Pidana dan Pertanggungjawaban Pidana (Jakarta: BPHN, 1984) at 5051.

79 Muladi, Dwidja Priyatno, supra note 26 at 86. 
20 of Act No. 31/1999 (amended in Act No. 20/2001). Then, the corporate criminal liability adopted is included in the Act on the conservation of natural resources. In addition, their ecosystems can be cumulative-alternative, with the phrase "corporation and/or management." Corporations are subject to criminal law in the same way as natural humans; criminal sanctions imposed on corporations are criminal fines. In addition to criminal fines, corporations can also be given measures to restore the situation to the previous condition before the damage caused by a company's crime. The perpetrators of criminal offenses in Act on the conservation of natural resources and ecosystems are persons and corporations/legal entities. Both forms and formulations of criminal liability can be complementary. Through the revision of legislation, corporations today are accepted as legal subjects and treated the same as other legal subjects, namely humans (natural). Thus, corporations can act like humans.

\section{CONCLUSION}

The policy system for protecting animal crimes is set out under positive criminal law, including protected wildlife crime. This policy outlines three main points, inter alia, acts (crime problems), people (problems of fault or criminal liability), and a crime that highlights the importance of Act on the conservation of natural resources and ecosystems. However, this Act does not have an arrangement for protected wildlife trade crime for the corporation, which subsequently urges the necessary arrangements related to corporate criminal liability. This paper expects that the legislation relating to protected animals' criminal acts should outline criminal guidelines for corporations against the protected wildlife crime. In particular, it needs to cover the corporation's status as the subject of criminal acts, with the following criminal sanctions and considerable responsibility as the consequent actions.

\section{ACKNOWLEDGMENTS}

None.

\section{COMPETING INTERESTS}

The authors declare that they have no competing interests.

\section{REFERENCES}

Abdurrahman. Pembangunan Berkelanjutan Dalam Pengelolaan Sumber Daya Alam Indonesia. (2003) Makalah Seminar Pembangunan Hukum Nasional VIII, Badan Pembinaan Hukum Nasional Departemen Kehakiman Dan Hak Asasi Manusia RI.

Agus Budianto. Delik Suap Korporasi di Indonesia. (Bandung, CV. Karya Putra Darwati, 2012). 
Akhmad Safuan, "Penyelundupan Ratusan Burung Langka Digagalkan" (2019) online: Media Indonesia 〈https://mediaindonesia.com/read/detail/225754-penyelundupan-ratus an-burung-langka-digagalkan>.

Andi Hamzah. Hukum Pidana Indonesia. (Jakarta, Sinar Grafika, 2017).

Arif Firmansyah Herliyanto. Sanksi Pidana Terkait Perdagangan Ilegal Satwa Liar yang Dilindungi. (2019) 2:3 Jurnal Jurist-Diction.

Aulia Ali Reza. Pertanggungjawaban Korporasi dalam Rancangan Kitab Undang-undang Hukum Pidana. (2015) Aliansi Nasional Reformasi KUHP Jurnal Institute for Criminal Justice Reform (ICJR).

Baehaqi Almutoif, "Hukuman Pelaku Perdagangan Kukang Masih Rendah" (2019) online: Jatim Net 〈https://jatimnet.com/hukuman-pelaku-perdagangan-kukang-masih-rendah».

Barda Nawawi Arief. Kapita Selekta Hukum Pidana. (Bandung, Citra Aditya Bakti, 2003).

Basten Gokkon, "Indonesian Conservation Bill is Weak on Wildlife Crime, Critics Say" (2020) online: Mongabay 〈https://news.mongabay.com/2018/04/indonesianconservation-bill-is-weak-on-wildlife-crime-critics-say/>.

Cristina Maglie. Models of Corporate Criminal Liability in Comparative Law. (2005) 4:547 Washington University Global Studies Law Review.

Darwina Widjajanti. Pengantar Pemahaman Pendidikan Konsumsi Berkelanjutan (PKB) di Indonesia. (2014) Yayasan Pembangunan Berkelanjutan.

Della Syahni, "Soal Kejahatan Satwa Liar Masuk Revisi KUHP, Begini Pandangan Mereka" (2020) online: Mongabay 〈https://www.mongabay.co.id/2018/06/04/soal-kejahat an-satwa-liar-masuk-revisi-rkuhp-begini-pandangan-mereka/s.

Dewi Purningsih, "Kejahatan Satwa Liar dan Tanggungjawab Korporasi dalam RKUHP” (2020) online: Greeners 〈https://www.greeners.co/berita/kejahatan-satwa-liar-dan-tangg ungjawab-korporasi-dalam-rkuhp/>.

Didik Endro Purwoleksono. Hukum Pidana. (Surabaya, Airlangga University Press, 2013).

Fathi Hanif. Upaya Perlindungan Satwa Liar Indonesia Melalui Instrumen Hukum dan Perundangundangan. (2015) 2:2 Jurnal Hukum Lingkungan.

J.M. Van Bemmelen. Hukum Pidana I: Hukum Pidana Material Bagian Umum. (Bandung: Binacipta, 1986).

Jan Remmelink. Hukum Pidana (Komentar atas Pasal-Pasal Terpenting dari Kitab UndangUndang Hukum Pidana Belanda dan Padanannya dalam Kitab Undang-Undang Hukum Pidana Indonesia). (Jakarta, PT Gramedia Pustaka Utama, 2003).

Keisyah Aprilia, "UU Konservasi Lemah Hadapi Perdagangan Satwa Liar", (2019) online: Benar News 〈https://www.benarnews.org/indonesian/berita/uu-lemah-hadapiperdagangan-satwa-liar-05022018122431.html .

Kustin Ayuwuragil, "RKUHP Disebut Tak Bisa Bikin Jera Kejahatan terhadap Satwa”, (2020) online: CNN Indonesia 〈https://www.cnnindonesia.com/nasional/20180530163318 -12-302304/rkuhp-disebut-tak-bisa-bikin-jera-kejahatan-terhadap-satwa〉.

Loebby Luqman. Kapita Selekta Tindak Pidana di Bidang Perekonomian. (Jakarta: Datacom, 2002). 
Mardjono Reksodiputro. Pertangungjawaban Pidana Korporasi dalam Tindak Pidana Korporasi. (Semarang: FH-UNDIP, 1989).

Muhammad Yazid, "Akan Ada Hukuman Minimal Bagi Pemburu Satwa Langka", (2020) online: Nasional Kontan 〈https://nasional.kontan.co.id/news/akan-ada-hukuman-mini mal-bagi-pemburu-satwa-langka>.

Muladi. Pertanggungjawaban Pidana Korporasi. (2013) Harian Kompas.

Muladi Dwidja Priyatno. Pertanggungjawaban Pidana Korporasi. (Jakarta: Kencana Prenada Media Group, 2011).

Noor Endah Mochtar dkk. Pendidikan Untuk Pembangunan Berkelanjutan (Education Sustainable Development) di Indonesia: Implementasi dan Kisah Sukses. (2014) Komisi Nasional lndonesia untuk UNESCO (KNIU) Kementerian Pendidikan dan Kebudayaan.

Radesman Saragih, "Oknum Perbakin Jambi Tertangkap Jual Kulit Harimau”, (2020) online: Berita Satu 〈https://www.beritasatu.com/kesra/287990/oknum-perbakin-jambitertangkap-jual-kulit-harimau».

Rasamala Aritonang dkk. Tata Cara Penanganan Perkara Pidana Korporasi. (2017) Tim Pokja Penyusunan Pedoman Pertanggungjawaban Korporasi, Mahkamah Agung RI dan Komisi Pemberantasan Korupsi.

Reda Manthovani. Penuntutan Korporasi Sebagai Pelaku Tindak Pidana dalam Kejahatan di Sektor Kehutanan: Optimalisasi Penggunaan Undang-Undang Pencucian Uang dalam Pembuktian Tindak Pidana di Sektor Kehutanan di Indonesia yang Dilakukan oleh Korporasi. (2010) Jurnal Indonesian Corruption Watch.

Reza Septian, "Jalan Panjang Berantas Penyelundupan Satwa Liar Dilindungi", (2019) online: Mongabay 〈https://www.mongabay.co.id/2019/04/13/jalan-panjang-berantas-pen yelundupan-satwa-liar-dilindungi/>.

Rochmat Soemitro. Hukum Perseroan Terbatas Yayasan dan Wakaf. (Bandung, PT Eresco, 1993).

Roeslan Saleh. Tentang Tindak-Tindak Pidana dan Pertanggungjawaban Pidana. (Jakarta: BPHN, 1984).

Romli Atmasasmita. Asas-Asas Perbandingan Hukum Pidana. (Jakarta, Yayasan Lembaga Bantuan Hukum Indonesia, 1989).

Rudi Prasetyo. Perkembangan Korporasi dalam Proses Modernisasi dan Penyimpanganpenyimpangannya. (1989) Makalah Seminar Nasional Kejahatan Korporasi di FH UNDIP.

Sali Susiana. Pembangunan Berkelanjutan, Dimensi Sosial, Ekonomi dan Lingkungan. (Jakarta: Setjen DPR RI dan Azza Grafika, 2015).

State Ministry of Environment, "National Report on the Implementation of the Convention on Biological Diversity," online: 〈https://balaikliringkehati. menlhk.go.id/wp-content/uploads/l-first-national-report.pdf〉.

Sutan Remy Sjahdeini. Pertanggungjawaban Pidana Korporasi. (Jakarta, Grafiti Press, 2006). 
207 | LENTERA HUKUM

Wahyu Beny Mukti Setiyawan. Pertanggungjawaban Korporasi dalam Tindak Pidana Korupsi. (2014) 8:1 Jurnal Rechstaat Fakultas Hukum Universitas Surakarta. 
208 | Corporate Criminal Liability Against Biological Natural Resources and Ecosystems

This page is intentionally left blank 